\title{
Development Financing of Dispute Resolution Reform Projects: The Evolving Approach of the Asian Development Bank
}

\author{
Ramit Nagpal and Christina Pak*
}

\begin{abstract}
This chapter focuses on the developmental aspect of dispute resolution based on the experience of the Asian Development Bank (ADB) over the last twenty years. ADB has undertaken projects that support dispute resolution mechanisms in its developing member countries with the aim of achieving development impacts towards a more inclusive and sustainable economic development in Asia and the Pacific. This chapter posits that the promotion of dispute resolution through thematic or targeted interventions has yielded more effective results compared to larger-scale interventions through broader justice sector reform programs. This is demonstrated through ADB's recent experience financing and implementing technical assistance projects under its Office of General Counsel's Law and Policy Reform Program focused on environmental and climate change adjudication, access to justice in gender-based violence cases and creating and strengthening international arbitration laws to foster foreign direct investment and cross-border trade. АDВ does not necessarily shy away from ambitious investments in the justice sector, but recent experience has shown that through smaller, welltargeted interventions with strong ownership by key stakeholders within their absorptive capacity, it has been able to demonstrate meaningful impact in the area of dispute resolution.
\end{abstract}

* Ramit Nagpal, Deputy General Counsel, Asian Development Bank (ADB), rnagpal@adb.org; Christina Pak, Principal Counsel, ADB's Office of General Counsel, cpak@adb.org. The views expressed in this publication are those of the authors and do not necessarily reflect the views and policies of ADB or its Board of Governors or the governments they represent. ADB does not guarantee the accuracy of the data included in this publication and accepts no responsibility for any consequence of their use. The mention of specific companies or products of manufacturers does not imply that they are endorsed or recommended by ADB in preference to others of a similar nature that are not mentioned. By making any designation of or reference to a particular territory or geographic area, or by using the term 'country' in this document, ADB does not intend to make any judgments as to the legal or other status of any territory or area.

(C) ASIAN INFRASTRUCTURE INVESTMENT BANK (AIIB), 2019 | DOI:10.1163/9789004407411_012

This is an open access chapter distributed under the terms of the CC-BY-NC 4.o License. 
In development finance, dispute resolution is manifest at three levelsoperational, developmental and institutional. This chapter focuses on experience of the Asian Development Bank (ADB) at the developmental level in fostering dispute resolution mechanisms in its developing member countries (DMCs). It does not cover dispute resolution in ADB's operation areas, such as in $\mathrm{ADB}$ projects-for example, as it relates to the social and environmental impacts on the people affected by projects and procurement of goods, civil works and services in AD B projects. Also, this chapter does not cover the institutional aspects of dispute resolution - which address any formal claims made against $\mathrm{ADB}$ and how these interplay with $\mathrm{ADB}$ 's privileges and immunities.

Over time, ADB has undertaken a range of projects ${ }^{1}$ that foster dispute resolution mechanisms in its DMCs with the aim of achieving a more inclusive and sustainable economic development. AD в has provided loans to its DMCs to enhance access to justice and reforms to the judicial system to promote good governance through improvements in the rule of law. ADB has also financed thematic or targeted interventions, such as the creation of specialized 'green courts' or 'green benches' for administration of environmental justice, a specialized court for resolution of disputes related to gender-based violence (GBV) and assisted in enacting or strengthening arbitration laws to foster foreign direct investment (FDI) and cross-border trade in the South Pacific. Most recently, ADB's Infrastructure Referee Program aims to promote mediation and dispute resolution in infrastructure public-private partnership (PPP) projects.

This chapter provides an overview of ADB's earlier experience financing dispute resolution interventions as part of broader justice sector reform projects and the challenges in implementing these larger scale projects (Section 2). It then describes ADB's evolving approach under its Law and Policy Reform (LPR) Program ${ }^{2}$ financing and implementing dispute resolution reforms applying a

1 In this context, 'projects' include projects approved and implemented under various modalities, including technical assistance grants, investment projects and grants and program loans and grants.

2 'The central premise of ADB's LPR Program is that a functioning legal system is essential to sustainable development. A functioning legal system is anchored on the rule of law and comprises a comprehensive legal framework and effective judicial, regulatory, and administrative institutions that establish, implement, and enforce laws and regulations fairly, consistently, ethically, and predictably'. Christopher Stephens, AD в General Counsel. Under the LPR Program, ADB's Office of the General Counsel conceives, designs, processes, and implements technical assistance projects directly to developing member countries in areas relating to legal and judicial reforms. The LPR Program covers five different pillars-(i) environmental 
thematic and targeted approach under smaller-value technical assistance projects (TAs) (Section 3). In examining the two approaches, this chapter concludes (Section 4) that an incremental approach to dispute resolution reform in developing countries have been more effective than broader inventions in the justice sector based on the significant results achieved under ADB'S LPR Program. This chapter delves into the reasons why and shares ADB's experience.

ADB's earlier thinking was ambitious with the approval of larger-scale interventions aimed at holistic reforms in the justice sector. This was based on the premise that a comprehensive approach was more likely to succeed than smaller, piecemeal attempts at justice reform. In the early 2000s, AD B financed several sizable program loans to Pakistan, Bangladesh and Philippines aimed at wide-ranging justice sector reforms. These expansive interventions covered new court structures and laws, changes to governance, fiscal and human resource allocations, recommendations on mitigating court congestions and improving enforcement mechanisms. ${ }^{3}$

In December 2001, ADB approved its first and largest loan-financed justice reform program in the amount of US $\$ 330$ million for the 'Pakistan's Access to Justice Program' (AJP). ${ }^{4}$ The objective of the AJP was to improve access to justice for its citizens, the poor in particular, and address reforms relating to judicial processes and institutions, police and public safety, prosecution, administrative justice and alternative dispute resolution. ${ }^{5}$ The AJP was expected to contribute to the government's efforts to transform the performance of the

law and sustainable development, (ii) infrastructure law and regulation, (iii) financial law and regulation, (iv) private sector development, and (v) inclusive growth and access to justice. See ADB, 'Law and Policy Reform Program' 2016.

3 ADB, 'RRP on Pakistan' 2001; ADB, 'RRP on Bangladesh' 2007; ADB, 'RRP on Philippines' 2008; ADB, 'RRP on Philippines' 2011.

4 The AJP included two policy loans and a technical assistance loan. A TA grant was also provided given the complex nature and huge agenda of the AJP. See ADB, 'RRP on Pakistan' 2001.

5 The two policy loans included six judicial outcomes: (i) better policy making, (ii) stronger judicial independence, (iii) greater efficiency, (iv) legal empowerment of the poor and vulnerable, (v) better judicial governance, and (vi) human resource development. It also contained six police reform outcomes: (i) insulation of police from interference, (ii) improved capacity, (iii) establishment of an independent prosecution service, (iv) greater police accountability and transparency, (v) better liaison between the police and citizens, and (vi) public awareness and protection of rights. See ibid. 
judiciary and the police. It involved 31 implementing agencies across the federal level and four provincial governments in Pakistan and required compliance with 64 policy actions. ${ }^{6}$

The AJP yielded mixed results despite its comprehensive nature. Due to its complexity, it could not be implemented as originally envisaged and implementation was delayed. ${ }^{7}$ The AJP was too ambitious, trying to cover too many areas in judicial reform. It was also too centrally managed at the federal level and supply-driven, without strong demand and support from key stakeholders, including provincial governments. For example, a number of critical police reforms could not be effectively implemented due to lack of well-grounded agenda, clear mandate and capacity within the government to effectively implement them.

Furthermore, the implementation arrangements were too challenging for the executing and implementing agencies. The executing agency had never managed a program of this nature and the provincial agencies lacked experience in implementing complex reforms. The program had too many implementing agencies and the coordination framework was ineffective in resolving conflicts between the federal and provincial levels. The tension between the judiciary and the executive branch, and executive control of the program, also undermined program implementation at the local and provincial government levels. ${ }^{8}$

To support 'Bangladesh's Good Governance Program, ${ }^{9}$ a US $\$ 170$ million loan was approved in October 2007 to put in place comprehensive policy reforms in anticorruption, judicial administration, public service and sector

6 The Ministry of Law, Justice, Human Rights and Parliamentary Affairs was the overall executing agency for the AJP. At the Federal level, the implementing agencies were (i) the Law Commission, (ii) the Federal Ombudsman, (iii) the Federal Judicial Academy, and (iv) the Ministry of Interior. At the provincial level, the implementing agencies were the departments of law and home, with the planning and development department/board playing a coordination role. The provincial implementing agencies worked with (i) the provincial ombudsman, (ii) the High Court, (iii) the provincial public safety commission, as appropriate. See ibid.

7 The two policy loans were released in four tranches. The release of all but the first tranche was rescheduled because of difficulties in completing policy actions, many of which had to be implemented at both the federal and provincial levels, within the planned time frame. The first tranche was released on 24 December 2001 upon fulfillment of all the first tranche conditions. The incentive tranche was released on 20 November 2022, five months later than originally scheduled. The second tranche was released on 22 December 2004, 18 months later than originally scheduled. The third and final tranche was releases on 28 August 2007, 18 months later than originally scheduled. See ibid.

8 ADB, 'Completion Report on Pakistan' 2009.

9 The program was accompanied by a TA grant to support program implementation and capacity building of the executing and implementing agencies. See ADB, 'RRP on Bangladesh' 2007. 
governance..$^{10}$ This was another broad and complex program covering governance reforms through 47 policy actions in a wide range of areas. Implementation involved three tranches, with each tranche to be released upon the government's fulfillment of the agreed policy conditions. Adding to the complexities of reforms, implementation involved 17 executing and implementing agencies. ${ }^{11}$ Although the program yielded good results, ${ }^{12}$ there were implementation issues resulting from the complex and larger nature of the

10 These include, among others, separation of the judiciary, operationalization of Bangladesh Judicial Service Commission, reconstitution of the Anti-Corruption Commission and Public Service Commission, ratification of the United Nations Convention Against Corruption, implementation of the National Integrity Strategy, enactment of the Right to Information law and Whistle Blower Protection law, asset declaration by public servants and lower court judges, governance risk assessment in five key sectors, a grievance redress mechanism across the ministries, and establishment of the container terminal management system at the Chittagong Port Authority. See ibid.

They included: (i) Cabinet Division; (ii) Supreme Court; (iii) ACC; (iv) Law and Justice Division of the Ministry of Law, Justice and Parliamentary Affairs (MLJPA); (v) Legislative and Parliamentary Division of the MLJPA; (vi) Bangladesh Judicial Service Commission; (vii) Ministry of Shipping; (viii) Chittagong Port Authority; (ix) Ministry of Public Administration; (x) Public Service Commission; (xi) Economic Relations Division; (xii) Finance Division; (xiii) Ministry of Foreign Affairs; (xiv) Bangladesh Railway; (xv) Ministry of Education; (xvi) Power Division of the Ministry of Power, Energy and Mineral Resources; and (xvii) Ministry of Health and Family Welfare. See ibid.

12 The government completed separation of the judiciary from the executive in November 2007 through an ordinance, which was ratified by the Parliament in 2009. To ensure speedy disposal of cases pending in the high courts, during 2009-2017 the government appointed 47 judges to the High Court Division and 17 judges to the Appellate Division of the Supreme Court. Between 2007 and March 2018 the Bangladesh Judicial Service Commission recruited about 1,500 judges for the lower courts to support separation of the judiciary. The separation of the judiciary from the executive has led to improvement of the disposal of court cases. The Supreme Court has now assumed responsibility for most judicial and administrative decisions relating to the lower courts. The judiciary took various steps to speed up court proceedings and to reduce delays in court judgments. In 2015, the Appellate Division disposed of 9,992 cases, whereas 8,007 cases were instituted. The High Court Division disposed of 37,753 cases while 70,940 cases were instituted. In the subordinate judiciary, about 1.4 million cases were disposed of whereas about 1.5 million new cases were instituted. The higher rate of case disposal indicates improved management and efficiency of the judiciary. A project of Tk23.88 billion is being implemented to establish chief judicial magistrate court buildings in all 64 districts. Alternative dispute resolution and legal aid instituted — to improve access to justice, both the civil and criminal code procedures were amended in 2012 to incorporate the alternative dispute resolution process for quick disposal of cases and disputes. Under the Legal Aid Services Act, 2000, the National Legal Aid Services Organization was established by the government and is responsible for implementing government legal aid across the country. District legal aid offices have been established in all 64 districts with a view to ensuring access to justice for the poor and disadvantaged. See ADB, 'Progress Report on Tranche Release for Bangladesh' 2018. 
program. The program was extended eight times for 78 months, from original loan closing date of 31 March 2012 to 30 September 2018, in an attempt to fulfill the remaining tranche release conditions. These policy conditions were not met and eventually were waived, as follows: (i) establishment of an office of the ombudsman,;3 (ii) Parliament's ratification of an ordinance relating to legislation prescribing specific qualifications for the recruitment of Supreme Court judges; and (iii) Parliamentary ratification of an ordinance relating to legislation for the creation of an independent and competent prosecution or attorney service. ${ }^{14} \mathrm{ADB}$ and the government had extensive discussions and agreed to waive these conditions to close the program. ${ }^{15}$

In December 2008, ADB approved the 'Philippines' Governance in Justice Sector Reform Program', comprised of two program loans. It identified binding constraints such as lengthy judicial processes resulting in delayed case resolution and lack of impartial and accessible judicial system, which affect investor confidence and hampers economic development. Also delays in criminal proceedings, weak capacity, lack of coordination, and jail overcrowding undermine the criminal justice system in the Philippines. A first US $\$ 300$ million subprogram loan approved in 2008 focused on increasing resources to the justice sector and supporting the efficient delivery of justice service..$^{16} \mathrm{~A}$ second US $\$ 300$ million subprogram loan approved in 2011 focused on building institutional capacity to deliver justice services to communities and implement measures to address key justice sector priorities. ${ }^{17}$

The program was designed to address weaknesses in the judiciary and justice sector institutions that are mainly caused by inadequate resources, made worse by weak financial management. The lack of resources in the justice

13 The government established an office of Tax Ombudsman in 2005 but this was abolished in 2015 as it could not deliver the intended results. This setback with the office of the Tax Ombudsman has made the government hesitant to establish the office of national ombudsman since it is not certain about its outcome. Instead, the government implemented alternative measures such as the grievance redress system across the government and claimed that it had partially complied with this condition by implementing alternative measures. See ibid.

14 The Supreme Court lawyers, who are also members of the major political parties, strongly opposed the implementation of these two conditions as it may reduce the changes for some lawyers to become Supreme Court judges or government attorneys as the proposed laws require such selection based on specific criteria. Therefore, strong resistance from the influential legal practitioner community has delayed implementation of these conditions. The government requested ADB to waive these two policy conditions. See ibid. The Bangladesh's Good Governance Program has recently closed and the program completion report is under preparation. See ibid.

16 ADB, 'RRP on Philippines' 2008.

17 ADB, 'RRP on Philippines' 2011, 3. 
sector was undermining the capacity to meet institutional mandates and performance targets. It had also created conditions that jeopardized the integrity of justice sector agencies and their staff and weakened the independence of the courts. As the executing agencies, the Supreme Court and the Department of Finance implemented the two subprograms, coordinating among the implementing agencies (the Supreme Court, the DOJ, the DILG, the DBM, and the Office of the Solicitor General); program administration; disbursements; maintenance of all program records; and reporting to ADB. The implementation period for (i) subprogram 1 was from January 2006 to July 2008 and (ii) subprogram 2 was from September 2009 to August 2010, which was extended until March 2012 due to slower than expected progress.

While the Philippines program was rated successful in terms of relevance and delivering results, the sustainability of the program was rated as unlikely.18 Positive impacts were generated but once the program finished, the judicial reforms did not have the sustained support and commitment over the medium to long term. Weakness in addressing rising backlog of cases and congestion in prisons continued. Furthermore, the budgetary allocation to the judiciary in the government's national expenditure program fell below $1 \%$ of the total government expenditure. In fact, targeting a $1 \%$ allocation of total expenditures was one of the policy conditions. The post-program assessment noted more focus on capacity and institutional development to ensure sustainability.

Overall, the three large-scale program loans proved too ambitious, overly complex in design and implementation, and beyond the institutional capacity of the agencies involved. This hampered the likelihood of the sustainability of the reforms.

Since 2009, ADB's Office of the General Counsel under its LPR Program, has been taking a different approach particularly effective in the area of dispute resolution. ${ }^{19}$ AD в began targeting interventions thematically, addressing specific needs of its DMCs with clear objectives consistent with its strategic framework allowing for systematic and longer-term engagement and ensuring that

18 ADB, 'Completion Report on Philippines' 2017.

19 Please note that Section 3 focuses on the experience of ADB's Office of General Counsel under its LPR Program and not based on the experience of ADB as a whole. This subsection does not take into account legal and justice sector projects under other ADB departments. 
key stakeholders have the capacity to implement. These interventions prioritized engagement and ownership by key stakeholders thereby contributing to the success in achieving the objectives and sustainability of reforms.

\subsection{Environmental and Climate Change Adjudication}

For almost ten years, ADв has worked with Asian judiciaries to strengthen their capacity to effectively adjudicate environmental disputes, and more recently, climate change disputes, through several incremental technical assistance projects (TA). Work began under a small-scale regional TA 'Strengthening of Judicial Capacity to Adjudicate Upon Environmental Law and Regulations'.20 Under this TA, ADB, along with the United National Environmental Program (UNEP), convened the inaugural Asian Judges' Symposium on Environmental Decision Making, the Rule of Law, and Environmental Justice in July 2010 to consider how to increase judicial capacity for environmental adjudication. ${ }^{21}$ At the conclusion of the Symposium, participants proposed the Asian Judges Network on the Environment (AJNE) to improve the quality of court rulings on environmental and natural resource cases, and achieve effective enforcement of environmental law in the region, supported by two subregional groups, namely the Association of Southeast Asian Nations (ASEAN) and the South Asian Association for Regional Cooperation (SAARC).

Building on the success of the small-scale TA, ADB approved a regional TA 'Building Capacity for Environmental Prosecution, Adjudication, Dispute Resolution, Compliance, and Enforcement in Asia' in December 2010.22 The aim of this regional TA was to strengthen the capacity of judges to better adjudicate environmental law cases to improve the implementation, compliance and enforcement of environmental laws in participating countries. It focused on supporting the chief justices and senior judiciary due to their direct and indirect influence on the legal system and environmental enforcement. ${ }^{23}$

20 ADB, 'TA Report for Strengthening of Judicial Capacity' 2009.

21 The Symposium convened about 110 judges, environmental ministry officials, and civil society representatives from Asia, Australia, Brazil, and the United States to share experience to strengthen the rule of law, environmental justice, and the ability of judges to decide environmental cases. UNEP noted that the Symposium was the largest gathering of judges and legal stakeholders dedicated to strengthening the rule of law and justice for the environment since the 2002 Global Judges Symposium in Johannesburg, South Africa. See ADB, 'The Proceedings of the Symposium' 2010.

22 ADB, 'TA Report for Building Capacity' 2010.

23 'The judiciary plays a critical role in environmental enforcement by enunciating principles of environmental law, facilitating the development of environmental jurisprudence, and leading the legal profession to pursue the integration of sustainable development and environmental justice within strong national rule of law systems. Judges need to have 
The TA employed a two-pronged approach in engaging the judiciary in improving the adjudication of environmental cases. Firstiy, it worked on the regional and subregional levels, in establishing the proposed AJNE and supporting SAARC and ASEAN. Second, the TA engaged on the national level and supported in-country pilot programs. ADB's Office of the General Counsel served as the executing agency and worked closely with supreme courts, high courts, environmental tribunals, and national prosecution and law enforcement officers. ${ }^{24}$

Initially, the TA supported two pilot countries-Indonesia and Pakistan emanating from the willingness of the chief justices of Pakistan and Indonesia to act as champions. ${ }^{25}$ As a result of the tremendous commitment by the senior judiciaries, significant outcomes resulted from ADB's assistance to Pakistan and Indonesia. In Pakistan, specialized 'green courts' or 'green benches' were established which were led by trained environmental law judges and facilitated by specialized court procedures drafted based on international best practices. ${ }^{26}$ In Indonesia, an environmental judicial certification program under which only accredited judges can serve as environmental judges was established in conjunction with the Ministry of Environment and the Supreme Court of Indonesia. ${ }^{27}$

Request for TA assistance increased to include other countries: Bangladesh, Bhutan, Cambodia, the People's Republic of China, India, Lao People's Democratic Republic, Malaysia, Myanmar, Nepal, Philippines, Sri Lanka, Thailand,

the knowledge and tools available to pursue such noble objectives'. See ADB, 'The Proceedings of the Symposium' 2010, 23.

24 ADB's Office of the General Counsel also worked closely with other development partners such as IUCN and UNEP as implementing partners, as well as relevant ADB departments to ensure full coordination. See ibid, 22.

25 During the 2010 Symposium, the chief justice of Pakistan, offered to host, in 2011, a regional roundtable for SAARC chief justices to gather momentum for environmental enforcement, and the chief justice of Indonesia made a similar offer for ASEAN countries. See ibid, 23 .

26 AD B also assisted Pakistan in developing an environmental law curriculum to be used in judicial training academies and in the creation of a special judicial committee for environment. See Khan, 13 May 2012; Dawn, 'Green Benches', 12 May 2012.

27 It was Indonesia's desire to better understand other regional and nonregional efforts in environmental jurisprudence and environmental courts and tribunals that began the AD B program. Since 1998, Indonesia has been training its judiciary in environmental law, however, to further strengthen the judiciary's capacity to adjudicate environmental cases, the Ministry of Environment entered into a memorandum of understanding (MOU) with the Supreme Court which established a program to certify judges as 'environmental judges' after they have completed a series of training and subject to ongoing conditions to retain their environmental expert status. See Sumanatha, July 2010. 
and Vietnam. ${ }^{28}$ Green courts or benches were also established in Bhutan, Malaysia and Philippines. In Sri Lanka, a South Asian Judges Training Centre on Environmental Rule of Law and Sustainable Green Development was set up to train judges. ${ }^{29}$ In Bhutan, ADB assisted drafting rules of procedure for environmental cases, and developed an environmental bench book for green bench judges which was a compendium of policies, laws and environmental case law. ${ }^{30}$

The TA resulted in the creation of the AJNE, the first-of-its kind judicial network in the world for sharing environmental cases, information and best practices, which is comprised of judges from the ASEAN and SAARC regions, as well as from Australia, Brazil, Fiji, Mongolia, New Zealand, the United Kingdom, and the United States of America. The AJNE events brought all environmental law stakeholders together-judges, prosecutors, environment ministry officials, environmental law experts, and civil society representatives-and provided a neutral platform to conduct frank discussions on environmental issues. The dedicated website (www.ajne.org) hosts numerous resources that can help judges adjudicate effectively, such as a legal database that brings together the laws, rules, regulations, and case law of different countries. ${ }^{31}$

Perhaps, the most satisfying outcome is that ADB's work with the judiciary was instrumental in enhancing environmental jurisprudence in Asia. For instance, one of AJNE's champion judges, Chief Justice Syed Mansoor Ali Shah of Pakistan's Lahore High Court, penned Ashgar Leghariv. Federation of Pakistan, et. al., ${ }^{32}$ which is recognized as groundbreaking and is being cited as a precedent even beyond Asia. The Leghari case has generated similar public interest litigation in India when a young girl filed suit in the National Green Tribunal against the government over its failure to prepare a carbon budget and a national climate recovery plan, specifically referencing the Leghari case..$^{33}$ The Leghari case has also inspired litigation in Europe, where the People's Climate ${ }^{34}$ case was brought before the European Union General Court of Justice by families, whose livelihood have been and will be put at risk by climate change.

28 ADB, 'TA Report for Building Capacity' 2010.

29 Ahsan and Busta 2014.

$30 \quad$ AJNE, 'Workshop on Environmental Adjudication' 2018.

31 AJNE has also resulted in international recognition of Asian judges and raised their profile in the fora on environment and climate change law. ADB ensured that Asian judges become members of the governing body of the newly established Global Judges Institute on Environment. See the International Union for Conservation of Nature 2018. EU General Court, People's Climate Case 2018. 
To continue its commitment, AD B approved the 'Developing Judicial Capacity for Adjudicating Climate Change and Sustainable Development Issues' TA in December 2016, to provide judges with capacity building on environmental and climate change issues and adjudication for sustainable development. ${ }^{35}$ Judges throughout the region realized that more disputes related to climate change will likely be brought before the courts as the effects and impacts of climate change intensify. However, they need help in strengthening their knowledge to understand the various aspects of climate change and other sustainable development issues. ${ }^{36}$ Undeniably, the region's judiciary will play an important role in climate change governance, particularly regarding mitigation and adaptation policies and plans. They will be called upon to interpret new environmental, climate change, and disaster risk reduction laws and determine rights. ${ }^{37}$

\subsection{Access to Justice for Women and Girls Affected by Gender-Based Violence}

A second example is the 'Legal Literacy for Women' TA project in Pakistan and Afghanistan which aims to provide access to justice to women and girls who

35 The initial approved TA amount is $\$ 944,000$. The TA implementation period is from December 2016 to January 2020. See ADB, 'TA Report for Developing Judicial' 2016.

36 So far, under the TA, ADB has convened two major conference on environmental and climate change adjudication in Pakistan and Myanmar, as well other capacity building and knowledge sharing activities. On 26 and 27 February 2018, the Asia Pacific Judicial Colloquium on Climate Change: Using Constitutions to advance Environmental Rights and Achieve Climate Justice was held in Lahore, Pakistan to assist and build capacity of judiciaries and legal stakeholders in Asia Pacific to implement constitutionallyentrenched environmental rights. It was also to provide materials to contribute to and be used in national judicial training institutes or organizations and facilitate dialogue on good practices in implementing environmental constitutionalism and advancing climate justice. See AJne, 'Asia Pacific Judicial Colloquium on Climate Change' 2018. On 29-30 October 2018, the Supreme Court of the Union, АDB and UNEP convened the Asia Pacific Judicial Conference on Environmental and Climate Change Adjudication in Nay Pyi Taw, Myanmar, which brought together judiciaries from the Asia and the Pacific to discuss the latest developments in environmental and climate change law and to discuss possible solutions. See AJNE, 'Asia-Pacific Judicial Conference' 2018.

37 Judges across Asia and the Pacific will likely have to manage matters relating to: (i) legal commitments, responsibilities, and rights flowing from international environmental agreements like the Paris Agreement; (ii) loss and damage due to floods and rising sea levels; (iii) actions against the state for failing to adequately regulate greenhouse gas emission reduction, actions against polluters for failing to meet emission reduction requirements, and actions on climate change in general; and (iv) review of government administrative decisions on matters such as environmental permitting. Consideration of such actions comprise rules of standing, including the ability of indirectly affected citizens to seek review of administrative decisions; transboundary litigation on climate change, climate displacement, evidentiary burdens, and climate change science; and international environmental dispute resolution, through litigation or alternative modes. 
are affected by GBV. ${ }^{38}$ The significant economic and social costs of GBV impact not only women and girls personally, but also their families and communities, the government, and the economy in general, which suffers from lack of women's participation in governance and the labor force. Without harnessing the talents, human capital, and economic potential of women and girls who make up half of Asia's population, a region free of poverty will not be possible. ${ }^{39}$

Interventions under the TA include: (i) strengthening the capacity of the government, civil society organizations, and legal and judicial officers to respond to clients on gender issues and to improve the access to justice for women; and (ii) increasing awareness of and support for women's legal literacy and access to legal aid and services through a positive media campaign. Implementing parties include community organizers, civil service organizations and government agencies. ${ }^{40}$

Even though there are laws to protect women, women's literacy is very low and women's legal literacy is even lower. ${ }^{41}$ Furthermore, the legal and judicial systems have a fluid attitude regarding legislation and the implementation and interpretation of laws in courts. To allow women to benefit from these laws, it is important to work closely with decision-makers in the formal and informal justice systems to ensure the understanding and proper use and application of existing legislative framework. Improving women's access to and ability to use legal tools will facilitate more effective and substantive gender mainstreaming.

The 'Legal Literacy for Women' TA has been focusing on tailored capacity development of the legal service providers such as judges, prosecutors, magistrates, and religious and community leaders, based on cultural sensitivities of each locality. ${ }^{42}$ Work began with training judges on gender sensitization

38 The 'Legal Literacy for Women' TA was approved in December 2015 in the amount of $\$ 750$,000 which has been increased to $\$ 1,433,000$. The completion date of the TA is December 2019. АDB, 'Legal Literacy for Women' 2015.

ADB, 'Gender Equality and Women's Empowerment Operational Plan' 2013. AD в has been employing gender mainstreaming to promote gender equality and women's empowerment across all ADB operations.

40 The partner government agencies are the Ministry of Law, Justice and Human Rights in Pakistan and the Ministry of Women's Affairs in Afghanistan.

41 Institutional mechanisms to support gender equality laws and policies exist at all levels of government in Pakistan, and its Constitutions legally mandates gender equality along with other human rights. Government of Pakistan, National Assembly of Pakistan. 1973. The Constitution of the Islamic Republic of Pakistan. Islamabad. Pakistan has also ratified all relevant UN treaties, including the Convention on the Elimination of All Forms of Discrimination against Women.

42 Given the very conservative and patriarchal mindsets in these countries, ADB put together a diverse team of expert trainers-including a former judge from South Australia Supreme Court, Human Rights and Sharia Law expert from Malaysia, development 
and laws, in Pakistan's Punjab province, the largest province and considered to be the epicenter of $\mathrm{GBV}^{43}$ The judicial training was initiated at the invitation of the Chief Justice of the Lahore High Court which has jurisdiction over Punjab and resulted in the training of more than 220 judges on (i) the basics of gender sensitization, (ii) national gender laws and culture of Pakistan, (iii) relevance of international standards, (iv) gender-sensitized judicial conduct in GBV cases, (v) gender-GBV against women, (vi) attrition and compromise; and (vii) children as witnesses and their giving evidence in court. ${ }^{44}$ Generally, both male and female judges had limited understanding about indirect and structural discrimination, special measures for vulnerable classes, affirmative action (which is included in the Constitution), and the difference between gender equality and gender equity. Most judges were not familiar with international law and the treaties that Pakistan had ratified on women and human rights. Furthermore, while judges were aware of physical or sexual violence, they did not seem to consider that psychological and economic violence is also part of GBV. 45

Notably, the work with the Punjab judiciaries resulted in the establishment of Asia's first model GBV court in Lahore in October 2017. ${ }^{46}$ The purpose of this specialized court is to enable cases on GBV to be prioritized and conducted in a gender-inclusive manner. The GBV court is presided over by a trained judge, prosecutor and staff. Special infrastructure for the court was also established including: (i) larger courtrooms so the distance between the victim, lawyers and audience is increased; (ii) e-court facilities so that women can give evidence through video transmission; (iii) screens alongside the witness box so that women who are victims of violence are not forced to see the offenders when giving evidence; (iv) provision of female support officers, female prosecutors, and other female personnel and, by developing special court procedures. Since the establishment of the GBV court in Lahore, the conviction rate in rape cases has risen from $2 \%$ in 2016 to $20 \%$ in $2018 .{ }^{47} \mathrm{ADB}$ also assisted

anthropologist and national law expert from Pakistan and Afghanistan, and a gender and development law expert from ADB.

43 According to the Punjab Commission on the Status of Women, 17,581 cases of G BV were reported in Punjab in 2016. This number does not reflect the many unreported GBV cases in Pakistan.

Training modules were customized to the needs of Pakistan and were based on an extensive needs assessment done in the country.

45 Ahsan, 24 November 2017.

46 Dawn, 'Court to Deal with Gender-Based Violence Cases Opens in Lahore' 24 October 2017.

ADB, 'Promoting Access to Justice', 27 November 2018; Jalil, 6 May 2018. 
the Punjab judiciary in notifying the Gender Equality Policy for its judges, the Guidelines to be Followed in Gender-Based Violence Cases, and the Practice Note for the model GBV court.

Work with the Punjab judiciaries concluded by institutionalizing the establishment of the GBV court and for sustainability of the judicial training, a cohort of 25 local judges were trained who could deliver the trainings as and where needed. ${ }^{48}$ Three gender law modules were also prepared as part of the regular mandatory training program at the Punjab Judicial Academy. ${ }^{49}$

The 'Legal Literacy in Women' TA also engaged in Afghanistan where violence against women is considered widespread ${ }^{50}$ even though Afghanistan's Constitution provides for the protection and advancement of women's rights. ${ }^{51}$ During the beginning of implementation in Afghanistan, due to the security concerns in the country, $\mathrm{ADB}$ and its consultants could not travel to various provinces especially those considered the most dangerous areas for women. Therefore, initial trainings were only implemented through the Empowerment Center for Women (ECW), a civil service organization. ${ }^{52} \mathrm{ADB}$, through the ECW, trained people from the informal justice sector (Jirgas, Panchayats, Shuras and Imams) on women's rights in Islam, referral mechanisms in the informal justice sector to the formal justice sector, effective mediation methodology and training on family law and the Eliminating Violence Against Women Law.

Moreover, through partnership with the Chief Justice and the Attorney General of Afghanistan, the trainings extended to the formal legal and justice

48 A trainer-the-trainers model is successful in leveraging limited resources to produce a multiplier effect and likely to result in more ownership by the implementing parties.

49 Additionally, the TA has worked on successful media campaign through 'truck art', where an initial batch of 20 trucks were painted with positive visuals and socio-legal messages for community awareness. See Pakistan Gender News, 20 October 2018. A second batch of trucks will be painted to be used as moving billboards. Also, puppet shows with folk music and positive message on law, Islam and culture were produced and presented in a few districts of Punjab province and live radio shows were presented with a lawyer and cultural practices experts. Short animated text messages and a national song on women empowerments is also under production.

50 Hasrat 2012; According to a 2008 national survey by Global Rights Afghanistan, $87.2 \%$ of Afghan women and girls face at least one form of sexual, physical, economic, and psychological abuse. See Afghan Women's Network 2009.

51 Islamic Republic of Afghanistan 2004. The Elimination of Violence Against Women Law passed in 2009 is the country's primary legislation on GBV and women's issues. Afghanistan is a party to the UN Convention on the Elimination of All Forms of Discrimination Against Women (CEDAW).

$5^{2}$ ECW is based in Kunduz province, an area with high level of GBV crimes and women's restricted access to justice. 
systems, including judges from all levels of courts and prosecutors. ${ }^{53}$ The training programs covered 10 modules on Afghan laws, Islamic Shariah, international law, and human rights law. Currently, the TA team is working with the Chief Justice to institutionalize these training through development of courses for the judicial training institute and structural reform of Violence Against Women Courts in Kabul. ${ }^{54}$

\subsection{Promotion of International Arbitration for a Better Investment Climate in the South Pacific}

The third example of thematic, targeted intervention is ADB's assistance to Pacific $\mathrm{DMCs}^{55}$ to create and strengthen their international arbitration laws. ${ }^{56}$ The South Pacific is one of the last few regions in the world without an effective legal framework to resolve cross-border commercial disputes through international arbitration. ${ }^{57}$ The absence of an international arbitration framework not only impedes FDI ${ }^{58}$ and cross-border trade but also stifles the flow of international climate finance and climate investments, which the South Pacific region urgently needs. ${ }^{59}$

53 In August 2018, the TA team conducted a needs assessment of judges and prosecutors handling elimination of violence against women cases in Afghanistan to prepare a customized and need-based training program. The needs assessment was done through focused group discussions with around 100 judges and prosecutors. Based on the earlier focus group discussions, a training program was designed and delivered to 140 judges and prosecutors handling elimination of violence against women cases in December 2018.

54 Additionally, a media campaign is under preparation in Afghanistan. ADB is working with a local art NGO to paint positive messages and visuals on prominent public walls in Kabul with government permits. These messages include awareness on women's right to education, inheritance, and dignity. These messages also condemn child and compensation marriages of women and girls. ADB is also working with a mobile theatre group and currently various short plays are being presented in five important provinces of Afghanistan on issues ranging from domestic violence to culturally sanctioned forms of violence. The TA team is now preparing animated text messages, and a national song so that positive awareness raising message can reach out to the entire nation.

55 ADB's 14 Pacific DMCs include: Cook Islands, Fiji, Kiribati, Marshall Islands, Federated States of Micronesia, Nauru, Palau, Papua New Guinea, Samoa, Solomon Islands, TimorLeste, Tonga, Tuvalu, and Vanuatu. Niue is currently undergoing the process to join ADB as a member.

$5^{6}$ The initial approved TA amount was $\$ 500,000$ and has been increased to $\$ 1,650,000$. See ADB, 'TA Report for Promotion of International Arbitration Reform' 2016.

$57 \quad$ Pak 2017.

$5^{8}$ Recent academic research supports that access to international arbitration leads to an increase in foreign direct investment flows. Myburgh and Paniagua 2016.

59 Morita and Pak 2018. 
In recent decades, international arbitration has become the principal means by which commercial disputes between entities in different countries are resolved. ${ }^{60}$ The success of international arbitration as a means of dispute resolution is that it is a bespoke disputes process aimed at providing expertise, speed, confidentiality, neutrality and, most importantly, enforcement of the resulting arbitral award in nearly 160 countries through the UN Convention on the Recognition and Enforcement of Foreign Arbitration Awards (NY Convention) ${ }^{61}$

When making investment decisions, international investors often consider whether a country is supportive of international arbitration, including, in particular, if the enforcement of foreign arbitral awards is locally supported, which is to say, whether the country has signed on to the NY Convention and has the legal framework to give effect to it. ${ }^{62}$

Globally, 159 of the 193 UN member States has adopted the NY Convention, however, the majority of the South Pacific countries have not signed onto the NY Convention: Kiribati, Federated States of Micronesia, Nauru, Niue, Palau, Papua New Guinea (PNG), Samoa, Solomon Islands, Timor-Leste, Tonga, Tuvalu and Vanuatu. In fact, only Cook Islands, Fiji and Marshall Islands have acceded to the NY Convention. Moreover, many of these countries do not have the domestic legal frameworks to support the recognition and enforcement of international arbitration agreements and foreign arbitral awards.

6o For example, in a recent survey conducted by Queen Mary University of London in 2018, $97 \%$ of respondents (in-house counsel, arbitrators, private practitioners, representatives of arbitral institutions, academics, experts and third party funders) surveyed prefer international arbitration to resolve cross-border commercial disputes because 'enforceability of awards', 'avoiding specific legal systems/national courts', 'flexibility' and 'ability of parties to select arbitrators'. See White \& Case 2018.

61 The NY Convention is widely recognized as a foundational instrument of international arbitration and provides a globally accepted and well-endorsed method of recognizing foreign arbitral awards in other signatory states. It creates a uniform international framework, which enables parties to international arbitration agreements to enforce foreign arbitral awards with relative ease as compared to foreign court judgements. Furthermore, the NY Convention narrowly limits appeals from an award, which makes international arbitration more attractive to parties seeking finality in commercial disputes. Once a party has obtained an award from the tribunal, that award can be enforced in any of the ratifying countries. While there is an international treaty to recognize and enforce foreign arbitral awards that applies in close to 160 countries, there is no international treaty of comparable reach on recognition and enforcement of foreign court judgments or mediated settlement agreements although it is expected the United Nations Convention on Mediated Settlement Agreements will be opened for signature in 2019 but uptake is unknown.

62 Foreign investors view arbitration as a way to mitigate risks by providing legal certainty on enforcement rights, due process and access to justice. See Pouget 2013. 
Since the beginning of 2017, ADB has been assisting its Pacific DMCs to accede to the NY Convention and implement the Convention through the enactment of new or updated arbitration laws, based on the UN Commission on International Trade Law (UNCITRAL) Model Law on International Commercial Arbitration, tailored for the country context and including international best practices.

One early success has been the enactment of the Fiji's International Arbitration Act in September $2017^{63}$ which implements Fiji's obligation under the NY Convention which they signed onto in 2010. It puts in place one of the most advanced legislative regimes worldwide, incorporating international best practices in international commercial arbitration with provisions adapted from the Australia International Arbitration Act, the Hong Kong Arbitration Ordinance and the Singapore International Arbitration Act. ${ }^{64}$ In essence, ADB's support to Fiji and other Pacific DMCs allows these countries to leapfrog to having one of the most advanced legislative regimes for arbitration in the world. To commence the Act, $\mathrm{ADB}$ and its international arbitration consultants assisted with drafting the related High Court Rules which was issued in November 2018. ${ }^{65}$

To further promote international arbitration and increase uptake by the Pacific DMCs, ADB convened the first-of-its-kind South Pacific International Arbitration Conference in February 2018, in conjunction with the Fijian government and UNCITRAL. This was attended by policy and law makers from 11 South Pacific countries, as well as judges, lawyers, private sectors, development partners and international speakers. ${ }^{66}$

After the South Pacific International Arbitration Conference, demand for international arbitration reform increased and $\mathrm{ADB}$ is also working with the governments of PNG, Timor-Leste, Samoa, Tonga and Palau. Recently, PNG's National Executive Council (Cabinet) approved the policy paper on international arbitration reform to proceed with accession to the NY Convention and implementation through a new arbitration law. ADB and its international arbitration experts were instrumental in assisting the PNG government with the legal and policy work required for the Cabinet approval.

63 International Arbitration Act (Fiji) 2017.

64 This brings Fiji's International Arbitration Act in line with leading international arbitration jurisdictions such as Hong Kong, London, Paris, and Singapore as well as Fiji's major trading partners.

65 High Court (Amendment) Rules (Fiji) 2018.

66 АDв, 'The Dawn of International Arbitration' 2018; АDв, 'International Arbitration Reform', 12 February 2018; Smulian, 12 February 2018; Chambers, 12 February 2018; Radio New Zealand, 13 February 2018; MinterEllison, 8 March 2018. 
ADB is backing up legislative reform with capacity building. Awareness raising workshops on international arbitration reform were delivered in Tonga ${ }^{67}$ and Fiji. ${ }^{68}$ For the implementation of the Fiji International Arbitration Act, trainings were delivered to the judiciary, lawyers and private sector and another series of trainings are planned for 2019. ADB is also supporting the PNG government in convening the second South Pacific International Arbitration Conference to take place in March 2019 in Port Moresby, ${ }^{69}$ as well as the delivery of trainings for the implementation of the proposed new arbitration law. ${ }^{70}$

\subsection{Dispute Resolution in Infrastructure PPP Projects}

$\mathrm{ADB}$ is also attempting to promote dispute resolution through mediation in infrastructure PPP projects. AD B and other international financial institutions have identified infrastructure development as a crucial component of any poverty alleviation strategy in developing countries. According to AD B's 'Meeting Asia's Infrastructure Needs' report, ${ }^{71}$ infrastructure needs in developing Asia will exceed \$22.6 trillion through 2030, or \$1.5 trillion per year, if the region is to maintain growth momentum. The estimates rise to over $\$ 26$ trillion, or $\$ 1.7$ trillion per year, when climate change mitigation and adaptation costs are incorporated. ${ }^{72}$

Due to the long-term nature of complexities and sensitivities involved, many of the infrastructure PPP projects, tend to face challenges and roadblocks, during different phases and for various reasons, resulting in delays in completion or termination of contracts. Hence, effective resolution of disputes in infrastructure PPP projects is critical in delivering the much needed infrastructure in developing Asia.

67 Ministry of Information and Communication Tonga, 20 September 2017.

68 At the opening of the Fiji workshops, Chief Justice Anthony Gates noted that 'expertise in this field will enhance our reputation, and more importantly it will re-assure the rest of the world that Fiji is a safe place in which to invest and to do business. I hope therefore we can continue these workshops in order to achieve the necessary familiarity with the target groups'. See Gates 2017.

69 The Second South Pacific International Arbitration Conference will be convened under the wider International Mediation and Arbitration Conference, organized by the National and Supreme Court of PNG. See Arnold, 7 December 2018; IMAAC 2019.

70 Under a separate TA, ADB is also training Myanmar judges on the adjudication of commercial disputes under the new Myanmar Companies Law, draft Myanmar Insolvency Law (Myanmar Debtors Rehabilitation and Liquidation Bill), and the enforcement of foreign judgments and foreign arbitral awards in Myanmar. ADB, TA Report for Republic of the Union of Myanmar, 2015.

71 ADB, 'Meeting Asia's Infrastructure Needs' 2017.

72 Ibid. 
In July 2018, AD B launched its Infrastructure Referee Program (IRP), a grantfunded initiative of ADB's Asia Pacific Project Preparation Facility, where parties in a PPP infrastructure project may obtain funding support and technical assistance for dispute prevention and resolution. ${ }^{73}$ The focus of the IRP is to provide a 'third party opinion' to public and private parties to resolve disagreements over risk allocation-mostly during the tendering and negotiation phases. It is well-recognized that disagreements over risk allocation frequently lead to renegotiation of PPP contracts. In fact, data shows that about one third of the PPP projects get renegotiated on this account. ${ }^{74}$

Under a memorandum of understanding, Singapore International Mediation Center will work with ADB to establish a panel of international mediators and experts with experience and skills in dispute resolution of infrastructure PPPS. Through the IRP, panelists will provide an independent, third-party opinion to resolve disagreements that may arise over the life of a PPP project. Qualified 'Infrastructure Referees' will be tasked with conducting due diligence on the respective positions and deliver their recommendation to both parties. Solution proposed by the Infrastructure Referees will be impartial and independent from any interests or positions of the relevant public and private parties as well as ADB. Nevertheless, the IRP is still in early days and the effectiveness of this program remains to be seen.

\section{4}

\section{Conclusion}

Through targeted and smaller interventions in select thematic areas, ADB, under its LPR Program, has been able to demonstrate meaningful impact in dispute resolution. A focused approach with clear objectives and well-grounded timelines with strong links to relevant strategies of the governments, has proven to be successful. The close relationships that ADв has cultivated over time with the implementing partners allowed parties to work more cohesively, resulting in stronger participation and ownership in the reforms. Moreover, TA projects designed and scaled-up within the absorptive capacities of key stakeholders are implemented more effectively and lead to successful outcomes. To this end, a well-informed and comprehensive needs assessment is critical to determine the need and capacity of the implementing partners on the ground. Ultimately, these reforms need to be sustained by the governments beyond the duration of ADB's assistance, but their outcomes have been remarkable so far.

73 ADB, 'ADB, SIMC Sign MOU', 11 July 2018.

74 Global Infrastructure Hub and Turner \& Townsend 2018. 


\section{Reference List}

Afghan Women's Network. 'Gender-Based Violence in Afghanistan' (Afghan Women's Network 2009) <www.aidsdatahub.org/sites/default/files/documents/Gender_ based_Violence_in_Afghanistan.pdf $>$ accessed 13 February 2019.

Ahsan I, 'Challenging Norms on Gender-Based Violence in Pakistani Courts' (Asian Development Bank, 24 November 2017) < http://blogs.adb.org/blog/challenging-normsgender-based-violence-pakistani-courts $>$ accessed 13 February 2019.

Ahsan I and Bueta G, 'Proceedings of The Third South Asia Judicial Roundtable on Environmental Justice for Sustainable Green Development' (Asian Development Bank 2014) < www.adb.org/sites/default/files/project-document/62277/44364-o1-reg-tar. pdf $>$ accessed 12 February 2019.

Arnold M, 'Preparations Underway for First Med-Arb Meet Next Year' Papua New Guinea Post-Courier (National Capital District, Papua New Guinea, 7 December 2018) <http://postcourier.com.pg/preparations-underway-first-med-arb-meet-nextyear $/>$ accessed 13 February 2019.

Asian Development Bank, 'Report and Recommendation of the President to the Board of Directors on Proposed Loans and Technical Assistance Grant to the Islamic Republic of Pakistan for the Access to Justice Program' (Asian Development Bank 2001) < www.adb.org/sites/default/files/project-document/71344/rrp-32023.pdf > accessed 12 February 2019.

Asian Development Bank, 'Report and Recommendation of the President to the Board of Directors: Proposed Program Loan and Technical Assistance Grant Peoples Republic of Bangladesh-Good Governance Program' (Asian Development Bank 2007) < www.adb.org/sites/default/files/project-document/6569o/37017-ban-rrp. pdf $>$ accessed 12 February 2019.

Asian Development Bank, 'Report and Recommendation of The President to The Board of Directors: Proposed Program Cluster, Loan for Subprogram 1, And Technical Assistance Grant Republic of The Philippines-Governance in Justice Sector Reform Program' (Asian Development Bank 2008) < www.adb.org/sites/default/ files/project-document/67621/41380-phi-rrp.pdf $>$ accessed 12 February 2019.

Asian Development Bank, 'Completion Report: Pakistan-Access to Justice Program' (Asian Development Bank 2009) <www.adb.org/sites/default/files/projectdocument/63951/32023-01-pak-pcr.pdf $>$ accessed 12 February 2019.

Asian Development Bank, 'Technical Assistance Report for Strengthening of Judicial Capacity to Adjudicate Upon Environmental Laws and Regulation' (Asian Development Bank 2009) < www.adb.org/projects/43572-012/main> accessed 12 February 2019 . 
Asian Development Bank, 'Asian Judges Symposium on Environmental Decision Making, the Rule of Law, and Environmental Justice: The Proceedings of the Symposium' (Asian Development Bank 2010) <www.adb.org/sites/default/files/ publication/29631/symposium-environmental-decisions-law-justice.pdf > accessed 12 February 2019.

Asian Development Bank, 'Technical Assistance Report: Building Capacity for Environmental Prosecution, Adjudication, Dispute Resolution, Compliance, And Enforcement in Asia' (Cofinanced By the Regional Cooperation and Integration Fund Under the Regional Cooperation and Integration Financing Partnership Facility) (Asian Development Bank 2010) <www.adb.org/sites/default/ files/project -document/62277/44364-o1-reg-tar.pdf > accessed 12 February 2019.

Asian Development Bank, 'Report and Recommendation of the President to the Board of Directors: Proposed Policy-Based Loan for Subprogram 2 and Technical Assistance Grant to the Republic of The Philippines For the Governance in Justice Sector Reform Program' (Asian Development Bank 2011) <www.adb.org/ projects/41380-023/main> accessed 12 February 2019.

Asian Development Bank, 'Gender Equality and Women Empowerment Operational Plan, 2013-2020: Moving the Agenda forward in Asia and the Pacific' (Asian Development Bank 2013) <www.adb.org/sites/default/files/institutional-document/33881/ files/gender-operational-plan.pdf $>$ accessed 13 February 2019.

Asian Development Bank, 'Regional: Legal Literacy for Women' (Asian Development Bank 2015) <www.adb.org/projects/49149-001/mainproject-overview> accessed 13 February 2019.

Asian Development Bank, 'Technical Assistance Report for Republic of The Union of Myanmar: Strengthening Law, Regulation, And the Legal Profession for A Better Investment Climate' (Asian Development Bank 2015) <www.adb.org/ projects/49287-001/main > accessed 13 February 2019.

Asian Development Bank, 'Law and Policy Reform Program: Effective Legal Systems for Sustainable Development' (Asian Development Bank 2016) <www.adb.org/ publications/law-and-policy-reform-program $>$ accessed 12 February 2019.

Asian Development Bank, 'Technical Assistance Report for Promotion of International Arbitration Reform for Better Investment Climate in the South Pacific' (Asian Development Bank 2016) <www.adb.org/projects/50114-001/main> accessed 13 February 2019.

Asian Development Bank, 'Technical Assistance Report: Developing Judicial Capacity for Adjudicating Climate Change and Sustainable Development Issues' (Asian Development Bank 2016) <www.adb.org/projects/50177-001/main\#project-overview> accessed 13 February 2019. 
Asian Development Bank, 'Meeting Asia's Infrastructure Needs' (Asian Development Bank 2017) <www.adb.org/publications/asia-infrastructure-needs> accessed 13 February 2019.

Asian Development Bank, 'Completion Report: Philippines-Governance in Justice Sector Reform Program' (Asian Development Bank 2017) <www.adb.org/sites/ default/files/project-documents/41380/41380-023-pcr-en.pdf $>$ accessed 12 February 2019 .

Asian Development Bank, 'ADB Promoting Access to Justice to Fight Gender-Based Violence' (Asian Development Bank 27 November 2018) <www.adb.org/news/ adb-promoting-access-justice-fight-gender-based-violence $>$ accessed 13 February 2019.

Asian Development Bank, 'ADB, SIMC Sign MOU to Provide Dispute Resolution Expertise for PPPs' (Asian Development Bank 11 July 2018) <www.adb.org/news/ adb-simc-sign-mou-provide-dispute-resolution-expertise-ppps $>$ accessed 13 February 2019.

Asian Development Bank, 'The Dawn of International Arbitration in The South Pacific: Regional International Arbitration Conference' (ADB Knowledge Event Repository 2018 )<http://k-learn.adb.org/learning-events/dawn-international-arbitrationsouth-pacific-regional-international-arbitration > accessed 13 February 2019.

Asian Development Bank, 'International Arbitration Reform Needed to Improve Pacific's Access to International Markets, Investment' (Asian Development Bank 12 February 2018) <www.adb.org/news/international-arbitration-reform-needed -improve-pacifics-access-international-markets $>$ accessed 13 February 2019.

Asian Development Bank, 'Progress Report on Tranche Release: Bangladesh—Good Governance Program (Third Tranche)' (Asian Development Bank 2018) < www.adb .org/sites/default/files/project-documents/37017/37017-013-prtr-en.pdf> accessed 12 February 2019.

Asian Development Bank, 'Report and Recommendation of the President to the Board of Directors: Proposed Program Cluster, Loan for Subprogram 1, and Technical Assistance Grant Republic of the Philippines: Governance in Justice Sector Reform Program' (Asian Development Bank 2018) <www.adb.org/projects/documents/govern ance-justice-sector-reform-program-subprogram-1-rrp > accessed 12 February 2019.

Asian Judges Network on Environment, 'Asia Pacific Judicial Colloquium on Climate Change: Using Constitutions to Advance Environmental Rights and Achieve Climate Justice' (Asian Judges Network on Environment 2018) <www.ajne.org/event/ asia-pacific-judicial-colloquium-climate-change $>$ accessed 13 February 2019.

Asian Judges Network on Environment, 'Asia-Pacific Judicial Conference on Environmental and Climate Change Adjudication (Asian Judges Network on Environment 2018)' <www.ajne.org/event/asia-pacific-judicial-conference-environmental-andclimate-change-adjudication\#quicktabs-event_tabs=1> accessed 13 February 2019. 
Asian Judges Network on Environment, 'Workshop on Environmental Adjudication for the Judiciary of Bhutan' (Asian Judges Network on Environment 2018) <www .ajne.org/event/workshop-environmental-adjudication-judiciary-bhutan $>$ accessed 12 February 2019.

Case T-330/18 Armando Ferrão Carvalho and others $v$ The European Parliament the Council [2018] EU General Court.

Chambers C, 'Convention Encourages Cross Border Trade' Fiji Sun (14 February 2018) <http://fijisun.com.fj/2018/02/14/convention-encourages-cross-border-trade/> accessed 13 February 2019.

Dawn, “Green benches" constituted in all high courts, AJK SC' Dawn (Karachi, 12 May 2012) < www.dawn.com/news/717870> accessed 12 February 2019.

Dawn, 'Court to Deal with Gender-Based Violence Cases Opens in Lahore' Dawn (Karachi, 24 October 2017) < www.dawn.com/news/1365866> accessed 13 February 2019.

Gates A, Opening Speech (Suvva, Fiji, 2017).

Global Infrastructure Hub and Turner \& Townsend, 'Managing PPP Contracts After Financial Close: Practical Guidance for Governments Managing PPP Contracts, Informed by Real-Life Project Data' (Global Infrastructure Hub 2018) <http://gihubmanagingppp-tools.s3.amazonaws.com/live/media/1465/updated_full-document _art3_web.pdf> accessed 13 February 2019.

Hasrat M, 'Violence Against Women in Afghanistan: Factors, Root Causes and Situation' (Afghanistan Independent Human Rights Commission 2012) <www.aihrc. org.af/media/files/Research\%2oReports/Dari/Report\%2oon\%2oViolence\% 20against\%2oWomen\%201390\%20_English-\%2ofor\%2ohasa.pdf> accessed 13 February 2019.

High Court (Amendment) Rules 2018 (2018) Legal Notice No. 85 <www.fiji.gov.fj/ getattachment/6a820747-2101-49ae-9b70-da111697do2b/LN-85---High-CourtAmendment-Rules.aspx $>$ accessed 13 February 2019.

IMAAC, 'International Mediation and Arbitration Conference 2019' (Imaacpng.org 2019) <http://imaacpng.org/> accessed 13 February 2019.

International Arbitration Act 2017 (Act No. 44) 2017 <www.fiji.gov.fj/getattachment/ d9502667-6491-4592-85b2-eff97f245fed/Act-44---International-Arbitration-Act .aspx $>$ accessed 20 February 2019.

Jaril X, '1,545 cases of violence against women recorded in Multan' Dawn (Karachi, 6 May 2018) <www.dawn.com/news/1405848> accessed 13 February 2019.

Khan A, 'Environmental Justice: Green Benches Constituted All Over Pakistan, AJK' The Express Tribune (Karachi, 13 May 2012) <http://tribune.com.pk/story/378089/ environmental-justice-green-benches-constituted-all-over-pakistan-ajk/> accessed 12 February 2019.

Leghari v Federation of Pakistan and others [2015] Lahore High Court Green Bench, W.P. No. $25501 / 2015$. 
Ministry of Information and Communication Tonga, 'International Commercial Arbitration-Convention on the Recognition and Enforcement of Foreign Arbitral Awards 1958' (Ministry of Information and Communication, 20 September 2017) <http://www.mic.gov.to/news-today/press-releases/6928-internationalcommercial-arbitration-convention-on-the-recognition-and-enforcement-of -foreign-arbitral-awards-1958> accessed 13 February 2019.

MinterEllisonRuddWatts LLP., 'Update from New Zealand: International Arbitration in The Region Is Full Steam Ahead' (Minterellison.co.nz, 8 March 2018) <http:// minterellison.co.nz/our-view/update-from-new-zealand-international-arbitration -in-the-region-is-full-steam-ahead $>$ accessed 13 February 2019.

Morita T and Pak C, 'Legal Readiness to Attract Climate Finance: Towards A LowCarbon Asia and the Pacific' (2018) 12 Carbon \& Climate Law Review <http://klearn.adb.org/system/files/materials/2018/02/201802-legal-readiness-attractclimate-finance-towards-low-carbon-asia-and-pacific.pdf> accessed 13 February 2019.

Myburgh A and Paniagua J, 'Does International Commercial Arbitration Promote Foreign Direct Investment?' (2016) 59 The Journal of Law and Economics.

Pak C, 'Pacific Needs A Voice in International Arbitration' (The Lowy Institute 2017) $<$ www.lowyinstitute.org/the-interpreter/time-pacific-embrace-international -arbitration> accessed 13 February 2019.

Pakistan Gender News, 'Advocating Female Education One Truck at a Time' (2018) $<$ www.pakistangendernews.org/advocating-female-education-one-truck-at -a-time/> accessed 13 February 2019.

Pouget S, 'Arbitrating and Mediating Disputes: Benchmarking Arbitration and Mediation Regimes for Commercial Disputes Related to Foreign Direct Investment' (2013) World Bank Policy Research Working paper $663^{2}<$ https://openknowledge .worldbank.org/bitstream/handle/10986/16849/WPS6632.pdf? sequence= 1\&isAllowed=y $>$ accessed 22 February 2019.

Queen Mary University of London and White \& Case LLP, 2018 International Arbitration Survey: The Evolution of International Arbitration (White \& Case LLP 2018).

Radio New Zealand, 'Pacific Considers Collective Arbitration on Trade and Investment' (Radio New Zealand 2018) < www.radionz.co.nz/international/pacific-news/350339/ pacific-considers-collective-arbitration-on-trade-and-investment $>$ accessed ${ }_{13}$ February 2019 .

Ridhima Pandey v Union of India [2017] National Green Tribunal of India, Original Petition.

Smulian M, 'International Systems Can Help Pacific Nations Resolve Trade Disputes' Public Finance International (London, 12 February 2018) <www.publicfinance international.org/news/2018/o2/international-systems-can-help-pacific-nations -resolve-trade-disputes $>$ accessed 13 February 2019. 
Sumanatha A, 'Certification for Environmental Judges Within the Judicial Training System of the Supreme Court of the Republic of Indonesia' (2010) < www.ajne.org/ sites/default/files/event/2052/session-materials/agung-sumanatha-certification -for-environmental-judges-within-the-judicial-training-system-of-t.pdf $>$ accessed 20 February 2019.

The Constitution of the Islamic Republic of Afghanistan 2004.

The International Union for Conservation of Nature, 'Global Judicial Institute on The Environment' (The International Union for Conservation of Nature 2018) <www .iucn.org/commissions/world-commission-environmental-law/wcel-resources/ global-judicial-institute-environment $>$ accessed 12 February 2019. 